\title{
NATION-BUILDING IN ROJAVA: PARTICIPATORY DEMOCRACY AMIDST THE SYRIAN CIVL WAR
}

\author{
Название Национальное строительство в Роджаве: демократия участия в условиях \\ на рус. яз. гражданской войны в Сирии
}

Ключевые Сирия, гражданская война, сирийские курды, Роджава, демократический конфеслова: дерализм

Аннотация: В условиях гражданской войны в Сирии местные курды успешно использовали ослабление центральной власти для того, чтобы построить собственную систему самоуправления, известную как Роджава. Несмотря на то, что курдские силы на севере Сирии с энтузиазмом продвигают антинационалистическую программу левого толка, они сами при этом находятся в процессе национального строительства. Их главный идеологический принцип демократического конфедерализма объединяет элементы гражданского национализма и революционного социализма с целью создания новой нации в Сирии, построенной на эгалитарных началах. Политическая система Роджавы основана на принципах демократии участия (партиципаторной демократии) и фредерализма, позволяющих неоднородному населению ее кантонов участвовать в самоуправлении на уровнях от локального до квазигосударственного. Хотя вопрос о признании Роджавы в ходе мирного процесса под эгидой ООН и политического урегулирования в Сирии остается открытым, практикуемый ей демократический конфедерализм может уже служить моделью инклюзивной партиципаторной демократии.

Keywords: Syria, civil war, Syrian Kurds, Rojava, democratic confederalism

Abstract: During the civil war in Syria the Syrian Kurds have managed to effectively use the weakening of the central government in Damascus to build a new kind of selfgovernment known as Rojava. While the Rojavan Kurds in the north of Syria enthusiastically propagate an antinationalist left-wing message, they are themselves in the process of building a nation. Their guiding ideology of democratic confederalism incorporates elements of civic nationalism and revolutionary socialism in order to construct a new nation in war-torn Syria along egalitarian lines. Rojava's political system is based upon participatory democracy and federalism - political principles that allow the area's heterogeneous population to take part in self-government at levels from local to quasi-state. While recognition of the Rojavan cantons in the course of the UN-mediated peace process and political settlement on Syria remains an open issue, Rojava's democratic confederalism can already serve as a model for inclusive participatory democracy.

DOI:10.20542/2307-1494-2016-2-15-36 


\section{Introduction}

The Syrian Civil War has been a boon for the Kurds, who have managed to build a new kind of self-government as the central state's control weakened. In July 2012 the Syrian Kurds declared a new government in the north of Syria, and over a short fouryear period, have created a society completely unlike those of their hostile neighbors. The fully autonomous Kurdish cantons in northern Syria - known as Rojava - are an advanced form of grassroots democracy based upon the principle of democratic confederalism. As the civil war continued to rage in Syria, Rojava emerged as one of the conflict's most active participants. It sought independence from "the Islamic State of Iraq and Syria" (ISIS) and various rebel groups supported by regional powers, including Turkey, and by the United States, while at the same time having achieved the maximum level of autonomy from the Bashar al-Assad government in Damascus.

In this article, based upon translated primary sources, review of scholarly articles, and English-language media, the cantons' political climate is analyzed through applying theories of nationalism. Although Rojava officially denies being a nationalist movement, it is in the process of building a new civic-minded nation within the war-torn boundaries of Syria. And even though the Rojavan socio-political resurgence epitomizes inclusive political organization, its ideology comes out of generations of left-wing Kurdish nationalism. This article analyzes the tension between Kurdish nationalism and antinationalist, communistic rhetoric within the socio-political and nation-building project of Rojava.

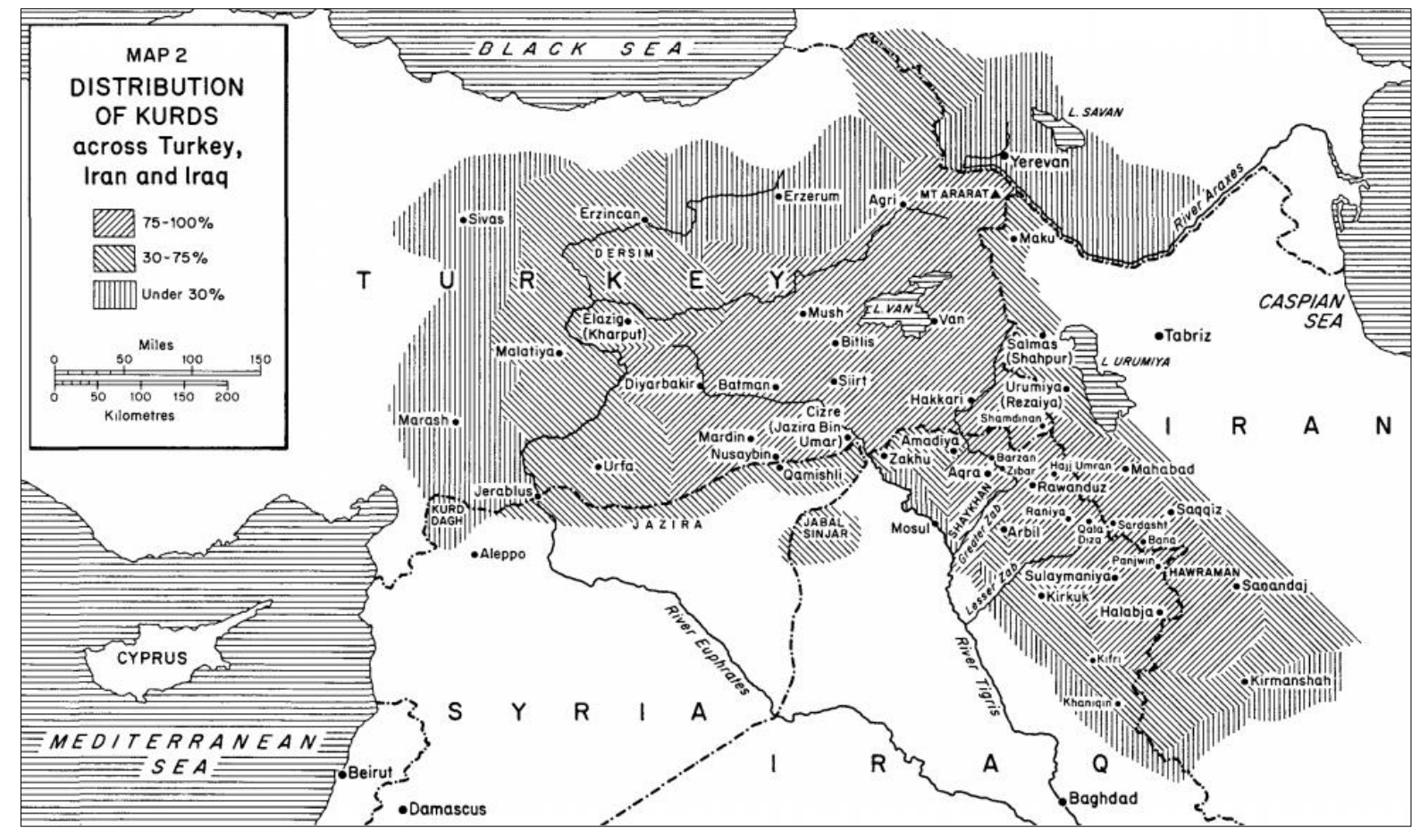

Source: McDowall D. A Modern History of the Kurds. - L.: I.B.Tauris, 2004. 


\section{Theoretical background}

It is necessary to define the terms nation and nationalism, since they will come up often in this article. Although these notions have been used for centuries, scholars debate their meanings to this day. In his 1882 lecture, Ernest Renan famously analyzed the civic nationalism born out of the French Revolution. Renan deemphasized the importance of race, language, or religion in determining whether or not a population/area is a nation, because all three phenomena regularly cross national boundaries. Instead he defined a "nation" as a spiritual principle, a massive solidarity of people united by a heroic past. National memories of suffering impose shared duties, most notably military service, that build loyalty to the nation. Renan used "a daily plebiscite" as a metaphor for the nation, demonstrating that local populations decide whether or not their nations exist. $^{1}$

In his indispensable book "Imagined Communities", Benedict Anderson analyzed the quasi-religious power of nationalisms and nations. Even though citizens cannot possibly meet all the members of even a very small nation, the nation is nonetheless perceived as a deeply horizontal comradeship. The cultural, almost religious power of an imaginary political territory is what makes masses of people even willing to die for the nation. Nations are conjured out of the geography of vernacular languages and old colonial borders, so they are inherently bounded concepts that assume international pluralism. ${ }^{2}$

Ernest Gellner, in his book "Nations and Nationalism", defined nationalism as a "political principle that holds that the political and national unit should be congruent". Gellner emphasized the modernity of nationalism, because modern education systems allow governments to unify state languages. Nationalism came to replace localized folklore cultures in urban areas. Now that communal agrarian economies are no longer commonplace, nationalism acts as a new form of community in the modern world. ${ }^{3}$

In her 1999 book, Montserrat Guibernau recognized the importance of nations and nationalist movements even when nations do not control a state. Whenever a group of people is referred to as a nation, the word implicitly acknowledges their right to selfgovernment. National self-government can be interpreted as either autonomy, or independence, depending on the nationalist movement's political power. If nations without states wield significant political power, they can demand fundamental reforms, such as a federative form of government. Federations (the Swiss cantons being a successful model that Rojava adopted) can effectively regulate ethnic and social conflicts. In the $21^{\text {st }}$ century, nations without states often embrace democratic principles, because democracy helps legitimize their political demands in the current global political climate. $^{4}$

Michael Hechter, in his book "Containing Nationalism", masterfully analyzed the conditions under which nationalism will thrive. Secessionist nationalism is galvanized by political centralization, which aggravates the disenfranchised subjects in the periphery. Whenever central rule collapses, which can be caused by a catastrophic war or 
economic weakness, nationalist movements abound. However, is influential politicians in the state's regions are offered meaningful posts in the central government, a federation can satisfy the nations within its boundaries. Most budgeting and governance can be devolved to local self-governments, while the federal government retains control over macroeconomic stability and international relations. When the federal constitution guarantees political power to all the regions - at both the local and federal levels - then national minorities are unlikely to mobilize for secession. ${ }^{5}$

Democratic confederalism, the guiding ideology of Rojava, is an advanced form of democracy practiced by a nation without a state. Responding to decades of heavyhanded Baathist centralization in Syria, Rojava embraces a federative form of government to achieve the maximum level of autonomy from the Syrian state. The cantons have constructed a deeply horizontal solidarity - bonded together by wartime necessity - that officially claims the northern portion of the Syrian state. The Rojavan cantons are an "imagined community" that believes politics should be congruent with the needs of the local people and that, if the cantons succeed at influencing the postwar settlement, a future Syrian constitution will guarantee both local autonomy and equitable representation for the Rojavans in Damascus.

\section{Kurdish national liberation movement during the $20^{\text {th }}$ century}

The current political project of Rojava is built upon a long history of Kurdish national liberation. Kurdish history goes back to the longstanding rivalry between the Ottoman and Persian Empires in the $16^{\text {th }}$ through the $19^{\text {th }}$ centuries. The Ottoman Empire entered a severe crisis before World War I. In 1908, the Young Turks reinstated the 1876 Constitution and began the Turkish period of constitutional monarchy. The Ottomans were on the losing side of World War I, so the victors forced the fallen empire to accept major land concessions. Syria and Lebanon fell under the French control and Iraq became a British colony. The old border with Persia held, and the new Republic of Turkey led by modernizer Kemal Ataturk abolished the sultanate and pushed European powers out of Western Anatolia. ${ }^{6}$

The international borders drawn after World War I divided the Kurds between four future independent states: Turkey, Syria, Iraq, and Iran. During the $20^{\text {th }}$ century all four of these unitary states sought to build modern republics along ethnic lines. Turkey aggressively promoted the Turkish language and culture over all others, going so far as to punish people speaking the Kurdish language in public with long prison sentences. Similarly, Syria and Iraq instituted chauvinistic policies of Arabization that banned all Kurdish names and cultural products. Although Iran was not as severe as its neighbors, it did not tolerate any dreams of a Kurdish autonomy within its borders. In all four of these countries, unitary states were built after histories of decolonization. In the process of their own nation-building, all these states treated the Kurds as a dangerous fifth column.

The main direction of the Kurdish politics underwent a major shift over the $20^{\text {th }}$ 
century. During the Ottoman Empire, the Kurds were generally ultraconservative, pledging loyalty to their own local clerics and the distant Sunni Khalifa, which at the time was claimed by the Ottoman sultan. After the consolidation of the Republic of Turkey, the Kurds gradually began to see the world along national and class lines. Kurds were increasingly hostile to the landlords who dominated the region and, as nations consolidated around them, began to view themselves as a nation too. The Kurdish national liberation movement played a very active role in the left wing of the 1978-1979 Iranian Revolution and in the socialist and communist parties in Iraq, both before and after Saddam Hussein rose to power. In Turkey, the Kurds formed the Kurdistan Workers' Party (PKK), which engaged in Maoist guerrilla war against the repressive central government. ${ }^{7}$

Despite many attempts at autonomy throughout the $20^{\text {th }}$ century, the Kurds remained politically marginalized in all respective states where they lived. As a result of the anti-Shah Revolution, Iran became a Shia theocracy where separatist movements were denounced as heretical. The Assad dynasty has ruled Syria Since 1970 with an iron fist, denying the Kurds citizenship for decades. Baathist Iraq was nationalist in the extreme, crushing all Kurdish calls for autonomy. In the late 1980s, Saddam Hussein even resorted to genocide against the Kurds, involving the use of chemical weapons. Turkey took a hard line against Kurdish autonomy throughout its entire history, often using collective punishment and forced deportations to intimidate and control the Kurds. In the early 2000s, Turkey allowed the Kurdish parties to participate in local and national elections, but that half-hearted reform was undermined by constant ethnic discrimination, most notably the ten thousand elected officials and political activists arrested between 2009 and 2013 on spurious charges of terrorism. ${ }^{8}$

Historically, the postcolonial Syrian government had a harsh relationship with the Kurds, who could not hold citizenship in the Syrian Arab Republic. In 2010 there were 300000 Kurds in Syria who were officially stateless. Despite the fact that Kurds composed $10 \%$ of the national population, the state refused to acknowledge their existence as an ethnicity, going so far as to argue that they were Turks or Iraqis nefariously imported into Syria by the former French colonizers. ${ }^{9}$ Hafez al-Assad (father of Syria's current president) further cracked down on the Kurdish community: as a police measure in the 1970s, Syria deported 140000 Kurds from the north and gave their lands to Arab settlers in an attempt to "improve" the ethnic mix of its northern borderlands.

Police discrimination was severe in Syria. In November 1963, Syria's internal security service commissioned a secret report, in which the influential Lieutenant Muhammad Talab Hilal described his views on Kurds starkly. His tone in the report reflected a profound hatred: "The bells of Cizire sound the alarm and call on the Arab conscience to save this region, to purify it of all this scum, the dregs of history until, as befits its historical situation, it can offer up its revenues and riches, along with the other provinces of this Arab territory.... The Kurdish question, now that the Kurds are organizing themselves, is simply a malignant tumor which has developed and been developed in a part of the body of the Arab nation. The only method that we can properly 
apply thereto is excision". 10

However, despite Syria's longstanding oppression of its Kurdish population, for almost 20 years the state cooperated with the Kurdistan Workers' Party, Turkey's arch nemesis. Turkey repeatedly built dams which severely limited Syria's fresh water supply, making Syria vulnerable to drought. Retaliation to Turkey's hydrological polices in part motivated Syria to give safe haven to the PKK between 1980 and 1999, allowing the rebels to direct their insurgency out of Damascus. This tense political bargain had one major condition, however. While Syria appreciated the PKK's war against Turkey, it would not tolerate any mobilization of the Kurdish population in Syria. The PKK obliged. Nonetheless, the Kurdistan Workers' Party's insurgency in Turkey was a powerful symbol of Kurdish resistance, which inspired the Rojavan Revolution a generation later. $^{11}$

The contemporary political climate in Northern Syria builds upon the legacy of the Kurdish national liberation movements of the $20^{\text {th }}$ century. Undoubtedly one of the most important Kurdish organizations in the broader region remains the PKK, which today provides military training to Rojavan soldiers. However, while Turkish Kurds are divided on whether the PKK is helping or hindering the Kurdish national liberation movement, Rojava has more universal popular support among the Syrian Kurds within the cantons. PKK is more radically separatist than the Rojavan cantons in Syria, as the organization renewed its insurgency against the Turkish government after the 2015 peace negotiations failed. Both Rojava and the PKK share Marxist ideology of national liberation, but the cantons already have their own self-government, while the PKK and its supporters are still struggling to achieve "liberated zones" in the militarized southeast of Turkey. Nonetheless, Rojava's tenets are in part motivated by Kurdish history outside the borders of Syria.

\section{The emergence of Rojava}

The decisive event in recent Syrian-Kurdish history was the Qamishli Riot in March 2004. During a local soccer match, fans from the visiting Arab team brandished portraits of Saddam Hussein, which in a Kurdish-majority area is the most offensive and inflammatory gesture possible. Angry stone throwing between the soccer fans quickly escalated into open political protests where local Kurds demanded cultural and political rights and razed the nearby Baath Party headquarters. Security services fired into crowds of Kurds, killing roughly one hundred people. A week later the government quelled the unrest, but it had a lasting impact on the Kurdish politics in Syria. The Kurds became convinced that any anti-Assad protest movement dominated by Arabs would not fight for cultural and political rights of the Kurds. Therefore, when the Free Syrian Army rose up against the Assad government in 2011, the Kurds did not join them. The Kurdish movement decided that it needed an independent militia movement - otherwise a new Arab regime would be just as oppressive towards the Kurds as the Assad dynasty. This political division between the Western-backed Free Syrian Army and the leftist Rojavan 
cantons was never resolved, and Rojava remains an independent political actor. ${ }^{12}$

As the Syrian civil war spiraled out of control, the Kurds were able to achieve de facto autonomy from the central government. In July 2012 the People's Protection Units (YPG) - Rojava's largest militia - quietly captured the cities of Kobani, Amuda, and Efrin. Assad's security forces withdrew with no major clashes, because the Assad regime prioritized more central territories over the Kurdish borderlands, as the Baathist government was increasingly fighting for its very survival. As the Kurds began their political experiment in Northern Syria, many current or former Baathist officials fled the region, leaving behind lands that Rojava redistributed communally. ${ }^{13}$

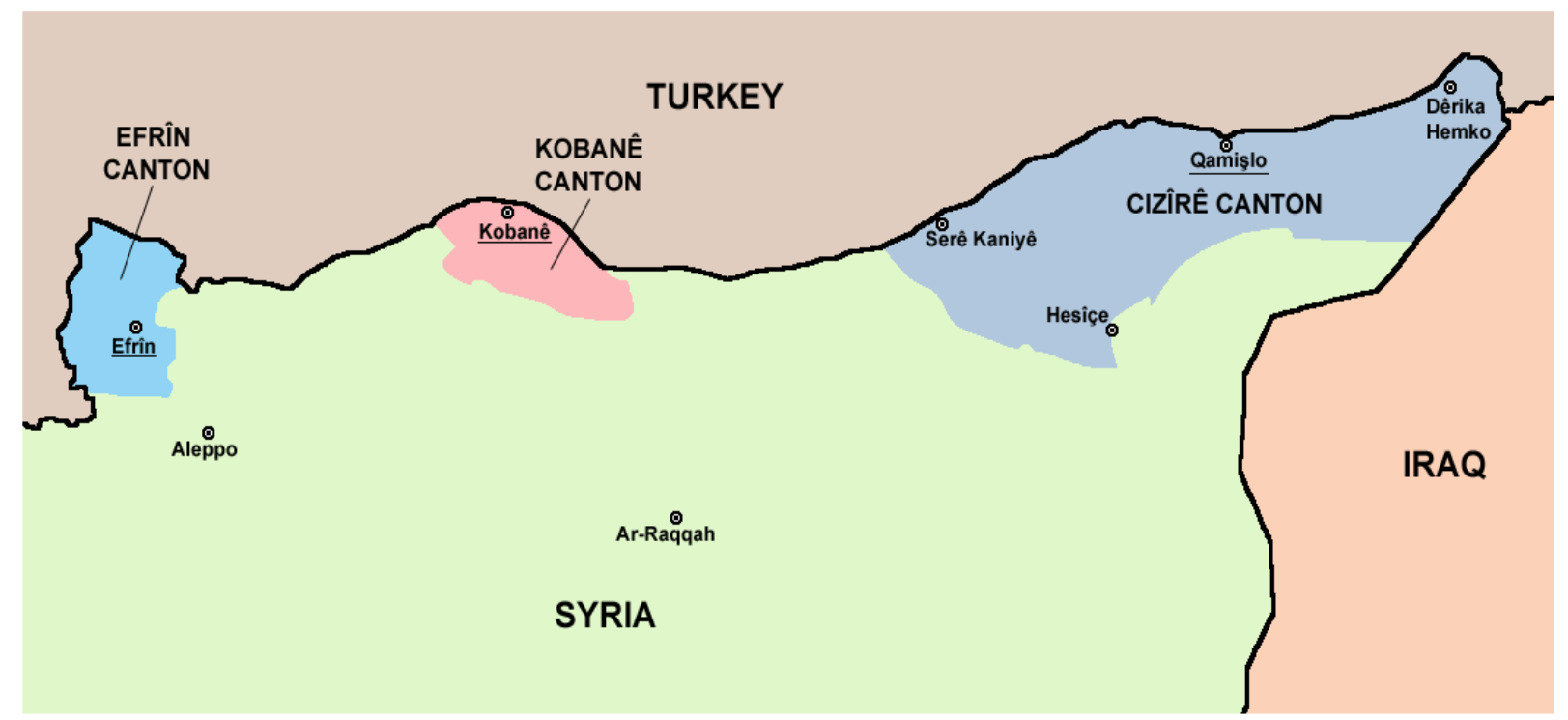

OOO - De facto cantons of Western Kurdistan (Rojava), as of February 2014

Right away the Syrian Kurds set up three non-contiguous cantons: Efrin, Kobani, and Cizire. The three cantons were autonomous islands stranded between various hostile governments: Turkey to the north, the Assad forces and antigovernment rebels to the west, ISIS to the south, and the Iraqi Kurdish Regional Government (KRG) to the east. The cantons were united by an ideology of national liberation of the Marxist bent. According to Rojava's ideology, since Kurds are the largest ethnicity in the world without a sovereign state, the roughly 30 million Kurds are labelled as an international colony. The Kurdish nationalist dream, which Rojava neither endorses nor rejects, has long been uniting the four divided parts in a united whole: Kurdistan. Nationalists call these parts Northern Kurdistan (in Turkey), Western Kurdistan (Rojava in Syria), Southern Kurdistan (the KRG in Iraq), and Eastern Kurdistan (in Iran). Although the goal of a united Kurdistan is utopian, it has motivated Kurdish political mobilization for generations, including a section of the Rojavan population that would prefer outright independence to political autonomy. ${ }^{14}$

The appearance and expansion of the Islamic State in Iraq and Syria (or Levant -ash-Sham in Arabic) in 2013 and 2014 came as a shock for the cantons, along with 
other communities living around the provincial capital of al-Raqqah. ISIS mandated the most conservative interpretation of Salafism (Sunni Islamic fundamentalism) and used very harsh methods to impose Islamist law and order, literally reproducing practices and punishments from the early stages of Islam, including mass killings of "apostates" (such as Shia Muslims) and killing and enslaving "pagans" (Yazidis). As a result, waves of refugees desperately fled north to Rojava. Many of the refugees were religious minorities who could not possibly survive under the ISIS rule, so the cantons were an indispensable safe haven for people fleeing the self-proclaimed "caliphate", even though many of those refugees continued north to Turkey or Europe. In particular, much of Rojava's current Yazidi population immigrated to the cantons during the ISIS expansion. ${ }^{15}$

In the second half of 2014 and the first half of 2015, ISIS aggressively pushed north towards Kobani, a strategic city and canton that they sought to conquer. ISIS invaded most of the canton and then charged into the city of Kobani, hoping to destroy one of the three cantons. Rojava heroically held the city of Kobani, its greatest military victory, but the devastation from the battle was absolute. Soldiers had to survive off of the food and supplies abandoned in the city, because nearly all its residents fled the advancing ISIS forces. Although Rojava triumphed in Kobani, both sides of the battle suffered high casualties. US air support proved invaluable during the siege, but, as a downside, approximately $70 \%$ of the city's buildings were leveled by bombing. The canton of Kobani held, but at a high cost. Rebuilding will undoubtedly prove to be a terrible challenge. ${ }^{16}$

Rojava achieved stunning military advances in the summer of 2015 due to high morale and massive air support from the US Air Force. Before the summer offensive, Kobani and Cizire cantons were isolated, separated by newly claimed ISIS territory and hostile Turkish government forces. Over the summer the two cantons boldly reversed ISIS' military advances, taking town after town along the Turkish border until the cantons were contiguous. When Kobani and Cizire cantons were isolated, they were vulnerable from multiple sides. Connecting the cantons increased the safety of Rojava's civilians, many of whom could now live without fear of imminent invasion. Following the military offensives in August 2015, the Kobani and Cizire Cantons formed a contiguous unit, but Efrin Canton still stood alone. ${ }^{17}$

Rojava has been trusted by none of its neighbors, including the Iraqi Kurdish Regional Government (KRG) to the east. Rojava has a tense relationship with the Iraqi $K R G$, because the KRG is far more conservative and right-wing, permitting both arranged marriages and Western-style capitalism. But what deeply unnerves the Kurdish cantons in Syria have been the KRG's business deals and historical alliance with Turkey, which continuously embargoes and sometimes shells Rojava. ${ }^{18}$

Turkey views the Kurdish national liberation movement as an existential threat. Turkey officially considers Rojava to be PKK by another name, stating quite clearly that any Kurdish autonomy is intolerable. In 2014 Erdoğan infamously declared that "For us, the PKK is the same as ISIL. It is wrong to consider them as different from each other." 
Not only does Erdoğan champion Turkey's longstanding opposition to Kurdistan, but he publicly equates Kurdish political parties with ISIS. Given the Turkish state's unequivocal opposition, it is not surprising that Turkey maintains a tight embargo against Rojava. All border crossings to the cantons are permanently closed, causing major supplies shortages in Rojava. ${ }^{19}$

\section{Ideology and governance in the cantons}

In 2013, Rojava consolidated as a political entity in the north of Syria. The Assad government's forces gradually withdrew from the north, because the government feared that even the capital of Damascus could fall to rebels. Pro-government troops were needed much more urgently in the center than in the periphery. The security vacuum was promptly filled by the Kurdish militias and popular committees consisting of locals. Interestingly, as Assad's garrisons slowly but steadily withdrew, there was a sort of dual power in Northern Syria. Policing gradually transitioned from state agencies to decentralized participatory democracy. Political change was much less violent in the north than in other parts of the country. ${ }^{20}$

The ruling coalition in the cantons is the Movement for a Democratic Society (TEVDEM). The largest political party within TEV-DEM is the Democratic Union Party (PYD), which also organizes the autonomous region's two most important militias: the People's Protection Units and Women's Protection Units (YPG and YPJ). The mixed-gender YPG has 50000 soldiers, while the YPJ consists of 10000 exclusively female fighters. The Rojavan soldiers elect all of their officers and they have achieved an impressive guerrilla army that specializes in sniping.

Although TEV-DEM, PYD, YPG, and YPJ promote very extensive social and political decentralization, they also have the organizing power to canalize the revolution into a productive direction. While most non-jihadist rebels in Syria are an incoherent mass incorporating many contradictory Islamist parties, Rojava is disciplined, staunchly secular, politically consistent, and quite popular. The cantons' strength lies in their ability to maintain a grassroots political movement involving both the Kurds and their left-wing allies. Rojava's real-existing socialist experiment gives it greater legitimacy than the plethora of antigovernment forces enjoying support from various regional powers and the West, who share no political platform beyond an obvious opposition to Assad. ${ }^{21}$

On 9 January 2014, Rojava officially proclaimed its autonomy. The Rojavan constitution guarantees minority rights and gender equality throughout the cantons. Naturally it also elaborates the procedures for democratic confederalism. Intriguingly, however, article 12 of the constitution clearly states that Rojava is "an integral part of Syria". This critical clause suggests that Rojava could agree to some sort of powersharing deal with the central government. No doubt the cantons want very wide autonomy, but they appear to see the Assad regime as less threatening than domination by either ISIS or Turkey. ${ }^{22}$

Rojava's system of self-government is based upon the philosophy of Abdullah 
Ocalan who had founded the PKK in 1978. After 20 years of the PKK insurgency in Turkey (logistically directed from Damascus), Bashar al-Assad's father Hafez finally expelled Ocalan from Syria. After he failed to get amnesty in Europe, in 1999 Ocalan flew to Nairobi, Kenya, where the CIA abducted him and handed the rebel leader over to the Turkish authorities. After being drugged and tortured, Ocalan was put in front of a TV camera, where he renounced the PKK's campaign to achieve an independent Kurdistan. Ocalan has spent the last 17 years alone in the ultra-secure Imrali island prison. During his incarceration Ocalan has become quite the scholar, reading everything from Michel Foucault to Benedict Anderson. ${ }^{23}$

In prison Ocalan got his hands on the works of Murray Bookchin, a thinker who was popular with the New Left of 1970s New York. Bookchin passionately denounced the authoritarian bent of political regimes and theorized that mankind's domination and destruction of nature mirrored the dominating character of class societies. Bookchin advocated an offshoot of anarchism, where collective decision-making at the local level would replace power relations. Ocalan thought that Bookchin's writings were brilliant, and they became the base of Ocalan's new political ideology. Hence Murray Bookchin became required reading for the most recent generation of Kurdish revolutionaries. ${ }^{24}$

The military stalemate between Turkey and the PKK in 2000 partly motivated Ocalan to adopt a new political doctrine. Since neither side could force the other to capitulate, Ocalan needed a new strategy that could survive the powerful Turkish army. Ocalan's newfound political goals were autonomy and democratic confederalism. Murray Bookchin's philosophy contributed to the evolution of the political goals Ocalan espoused for the Kurdish movement - from a traditional nationalist emphasis on overthrowing the capitalist state in order to found a communist one to building grassroots democracy and federal autonomy in areas where the Kurds already lived. As stated by Ocalan, "Has it not been nationalism and the nation-state which had created so many problems in the Middle East?" For the PKK insurgency, this implied a major political-ideological shift, so the rebel group needed years to relinquish the dream of national independence in favor of political autonomy. Ocalan's new ideology also profoundly affected the Kurdish national liberation movement in Syria: although Rojava is a de facto quasi-state, it is very clear in the movement's doctrine that it has a deep distrust of traditional nationalism and centralized state power. ${ }^{25}$

Despite serving a life sentence in the Imrali island prison, Ocalan remains the spiritual leader of the Kurdish resistance. Images of him are ubiquitous, and the Rojavan citizenry is fiercely loyal to their leader-in-perpetual-exile. For the last 5 years mass civic education has been a key priority for the Kurds, who greatly value the writings of Ocalan and other assorted leftists. The effects of this grassroots political mobilization are selfevident. The entire community participates in frequent meetings in open assemblies, people's councils, trade unions, town councils, and workplace cooperatives. ${ }^{26}$

"Popular councils, or "Houses of the People", make up the heart of the political system. The first level of organization is represented by [sic!] the local communes, each made up of 30-150 households. On the next level are [sic!] village and neighborhood 
councils, which consist of 7-30 communes each. This is followed by area councils and finally there is the MGRK, the People's Council of West Kurdistan. Decisions are conveyed from one level to the next by two delegates, one man and one woman, that are elected for this purpose." 27 These institutions of self-government encourage the participation of all citizens, regardless of their sex, age, race, religion, or political affiliation. In Northern Syria (Rojava), politics is no longer dominated by male elders and Damascus-appointed Baathist apparatchiki.

Political transformation manifests itself most clearly in terms of gender. All posts must meet a $40 \%$ gender quota and at every level of society - workplaces, political parties, assemblies, ministries, battalions - leaders are elected in tandem. There must be a male and a female co-president heading all offices in all institutions (the only exception being all-female organizations that would naturally have two women as copresidents). There is no section of Rojavan society where women are not included, because that would be contrary to the goals of the revolution. This successful shift in gender norms is especially impressive, because 5 years ago the idea of female soldiers, police officers, or politicians was considered ridiculous in Syria. ${ }^{28}$

Rojava is a secular and multiconfessional society. Its religious policy is based upon the French tradition of laïcité. Unlike in much of the Middle East, where religious conversions are either forbidden by the state religion or strongly discouraged by social pressures, in Rojava religious conversions and secularism are acceptable. Sunni Muslims, Orthodox Christians, and Yazidis freely change faiths, a process which bears no stigma. There are even a fair number of atheists, as Kurdistan retains a strong Marxist legacy from the 1960s. In sharp contrast to the Islamist groups that have grabbed so many headlines lately, Rojava wants religion to be a personal matter. ${ }^{29}$

Sunni Islam is the majority religion in West Kurdistan. Some women choose to wear traditional Muslim headdresses while others decide not to do so. Rojava is so secular that many Muslims decide not to fast during Ramadan, while in the nearby selfproclaimed "caliphate" such "apostate acts" would be punished with beheading. When ISIS expanded territorially, people who feared its harsh fundamentalist rule often fled to Rojava. Theses waves of refugees doubled the population of Northern Syria, offsetting the region's labor shortage and turning Rojava into a remarkably diverse place. ${ }^{30}$

West Kurdistan is not just for the Kurds, nor just for the Kurds and Arabs. Turkmens, Syriacs (also known as Assyrians, or Aramaeans), and Armenians are deliberately promoted to positions of influence, so that ethnic minorities have a real voice in the self-governance system. Political parties actively promote the interests of groups that have historically had little influence in the region. For example, during the 13 March 2015 Cizire Canton elections 565 candidates ran for office. Of those 565 candidates from a multitude of parties 237 were women, 39 were Assyrians, and 28 were Arabs. Furthermore, to guarantee positive action, the Rojavan constitution stipulates that the three highest offices in all organizations must be staffed by three different ethnicities. Positive action is taken very seriously in the cantons, because the revolutionaries want to create a strong connection between citizens and government. ${ }^{31}$ 


\section{Justice in Rojava}

Policing has been fundamentally transformed by the Rojava movement. The Asayis (community police) begin their training with two weeks of intensive education in feminist theory. Six weeks of more typical policing exercises only begin after the essential feminist education. All 6000 Asayis are elected directly by the community; the Asayis leadership is decided by further elections. ${ }^{32}$ The Asayis also have a specialized womenonly force that deals exclusively with domestic violence and sexual assault. Mental health care and women's shelters are a priority for Rojava and its community policing, because wartime trauma has made posttraumatic stress disorder (PTSD) very common. $^{33}$

Eliminating sexual harassment, rape, early and forced marriage, and polygamy are priorities for Rojava, so autonomous organizations have established women's houses throughout the cantons where these problems are resolved by women themselves. Although the women's houses and the Asayis have achieved remarkable success, cutting the rate of domestic violence in half, there is also some resistance to changing social norms. Some of the cantons' more conservative Muslims consider polygamy to be a religious right and many citizens deny the extent of sexual violence. Nonetheless, the movement is making steady progress against sexist violence and chauvinism more generally. ${ }^{34}$

The Asayis regret that they live in a warzone and therefore need to carry weapons. Rojava's community police aspire to be an unarmed constabulary that keeps the peace without coercion. Despite the troubles of war, they seem to be succeeding in building a communal bond. Rojava's civilians regularly salute their soldiers and Asayis in a comradely way and everyone in the cantons undergoes continuous education in civics and history. Despite the wartime emergency, the cantons abolished the death penalty. The Rojavans' long-term dream is for every single citizen to receive six weeks of police training, so that the formal police body can be dissolved after the war. ${ }^{35}$

Rojava's attitude towards crime is amazingly forgiving. Reconciliation between perpetrators and wronged parties is prioritized over punishment. The following incident is indicative of the new "social peace": "The next day, I attended a mass lunch where one family hosted another. A member of the first family had killed a man from the second: lunch marked the families' reconciliation, the culmination of a collective process of compensation, apology and forgiveness, where the perpetrator, briefly imprisoned, publicly acknowledged his crime. In turn, this act of contrition, supported by his family by means including the ceremonial meal, was accepted by the victim's relations. I asked the brother of the murdered man why he didn't want the killer to face further punishment. His eyes moist with grief, he replied, no: "social peace" was more important than punishment. This was a better way, he argued: what good would be served by a long punishment of the perpetrator?"36

This type of reconciliation between victims and criminals is typical of Rojavan 
justice. Instead of more traditional courts which the revolutionaries dismiss as manifestations of repressive state power, the cantons have instituted autonomous peace and justice committees. In these committees, disputes between "plaintiffs" and "defendants" are resolved by the active participation of the community that discusses and negotiates a solution to the problem. Instead of an emphasis on punishment, offenders are encouraged to take responsibility for their actions and mend their wrong towards the community at large. ${ }^{37}$

$90 \%$ of all legal disputes in the cantons are resolved either by the autonomous peace and justice committees or the women's houses that focus on crimes specific to women. However, when the communities' decisions are contested for whatever reason, cases can be appealed to the cantons' more formal appellate, regional, and constitutional courts where legal professionals will resolve criminal cases once and for all. Paradoxically, amidst the most brutal war in the world today, Rojava has been building a forgiving society, at least for its own members, and the one based upon participatory democracy. ${ }^{38}$

Since military service is considered a collective duty, local communities vote to decide who is to be conscripted to fight for the Rojava Revolution, which is taken very seriously in West Kurdistan. In addition to the ubiquitous Rojava tricolor flags, Ocalan posters, and banners for various political parties, martyr flags are everywhere in the cantons. The martyr flags have a very simple design: they are pictures of fallen revolutionaries. When citizens see martyr flags, they sometimes recognize an old neighbor or friend who died in the war. Even funerals for Rojava martyrs do not resemble Western burials at all. An unobservant foreigner could mistake a martyr's funeral for a wedding, since the celebration is so joyous. In the cantons, death in defense of the revolution is considered the greatest possible honor. YPG and YPJ fighters even say that martyrdom is beautiful. ${ }^{39}$

Despite the incredible degree of political mobilization in the cantons, the Rojava project does not receive everyone's support. Ten parties united to form the Movement for a Democratic Society (TEV-DEM) ruling coalition. This coalition is opposed by the Kurdish National Council (KNC), a coalition of 12 parties that criticizes a variety of Rojavan policies. The KNC coalition believes that TEV-DEM wields too much power and that the ruling coalition does not fight the Assad regime enough. Rojava allows the Syrian armed forces to control a part of Qamishli and al-Hasakah, a tacit agreement that has held despite repeated armed clashes. Many more traditional Kurdish nationalists think that this compromise is completely unacceptable and that the cantons deserve all of Northern Syria without exception, even if the Assad regime employees bring cash wages to the city of Qamishli. ${ }^{40}$

The rivalry between the TEV-DEM and KNC coalitions dates back to the 1990s, when the PKK was active in Iraq. TEV-DEM is allied with the PKK, because both movements are led by Ocalan's militantly anticapitalistic political philosophy. The KNC is allied with the pro-capitalist and pro-Barzani Kurdish Democratic Party (KDP), historically the most powerful party in Iraqi Kurdistan. The KDP has cooperated with 
Turkey for almost 25 years and in the 1990s KDP-controlled Iraqi Kurdistan allowed the Turkish troops to conduct an anti-PKK counterinsurgency on Iraqi soil. Due to the bad blood between TEV-DEM/PKK and KNC/KDP, Western and Southern Kurdistan are unlikely to get along in any foreseeable future. ${ }^{41}$

\section{Government services and the Rojavan economy}

In order to survive, Rojava has to organize militarily: $70 \%$ of its government budget goes to defense expenditures. Cheap AK-47s (Kalashnikovs), grenades, and uniforms need to be bought on the black market, because the cantons are unable to manufacture their own weapons. Rojava's annual military budget is only USD 20 million, but for the impoverished periphery that is a large amount of money. The cantons have no heavy weapons, but they have received air support from the United States, which has de facto acted as their air force. ${ }^{42}$

The government budget of Rojava is financed almost entirely by petrol sales to the Assad regime and the local population; import duties make up the remaining portion of government revenue. There are no taxes, which are denounced as statist. Rojava's oil rigs and refineries are operating at very low capacity due to few trading partners and a need for major repairs, and yet the cantons are able to fund both the war effort and social services. Rojava provides education, healthcare, and subsidized bread to the citizenry. The cantons buy bread at the market rate and then sell that bread at half-price, preventing widespread hunger. Since West Kurdistan is not an internationally recognized entity and is located within a major warzone, there is no foreign direct investment. Turkey completed sealed its long border with Syria with a reinforced concrete wall. The Iraqi KRG closes the critical border crossing to Rojava from time to time, depending on the diplomatic climate. ${ }^{43}$

In 2015 Rojava opened its first university, the Mesopotamia Academy of Social Sciences (under the Baathist regime Kurdish students had to move to Damascus or Aleppo in order to receive a higher education). Schools are free in all towns, as education is a top priority for both children and adults. After living under the heavily centralized, authoritarian government for decades, the Kurds needed to organize many seminars and adult education classes in order to teach citizens the basics of participatory democracy. Living under a single-party Baathist state is radically different from building a new confederation of people's councils, so the social transformation requires mass bottom-up political organization to create a new model of selfgovernment. ${ }^{44}$

Education in Rojava is multilingual, in sharp contrast to the Arabization policies of the Assad dynasty. After a century of cultural suppression in all four unitary states in which the Kurds reside, it was very tempting for the Rojavan Kurds to embrace ethnic nationalism and institute Kurdish as the only language of education and administration. However, Rojava has learned from the Middle Eastern history, and therefore bilingual education in Kurdish and Arabic is required. Learning a third language is strongly 
encouraged. Kurdish, Arabic, Aramaic, and Turkish are all popular languages to speak, learn, and read in the cantons. ${ }^{45}$

Healthcare is available in Rojava on a sliding pay scale. Those who can pay for medical care are urged to do so, while those who cannot are treated for free. The cantons have hospitals, medical clinics, and skilled workers to provide healthcare, but Rojava has an ongoing acute supplies shortage due to the Turkish embargo. The shortages are especially problematic in the delivery of healthcare where very specialized materials are needed for surgeries and pharmaceutical prescriptions. ${ }^{46}$

The democratic structure of Rojava is perhaps clearest in its economic organization. The Ministry of Economics reports that three-quarters of all property are community-owned, but there is still a small private sector. Local capitalists can and do expand their enterprises. However, when workers feel that the distribution of economic power is not functioning effectively, they may seize control of the means of production and set up a workers' council. "According to the Ministry of Economics, worker councils have only been set up for about one third of the enterprises in Rojava so far [in 2014]". ${ }^{4}$

Rojava is a mostly agricultural area, so the greatest number of cooperatives is in the farming area. Large landholdings used to be owned by powerful Baathist officials, but the cantons redistributed the lands to farmers' cooperatives. Northern Syria has long been the breadbasket of the country, producing a great deal of grains, fruit, vegetables, livestock, cotton, olives etc. Rojava is renovating its irrigation systems, because the cantons realize the precious value of water and ecological sustainability. The severe drought of 2008 is within recent memory, so building a new dam to increase the cantons' water supply was not controversial. Since Rojava is self-sufficient in food and fuel and manufactures most of its own supplies, the autonomous region has achieved a great deal of self-sufficiency. ${ }^{48}$

Much of Rojava's industrial base is light manufacturing geared towards food production. Olive processing plants and olive oil factories are particularly common, while there are also many soap, cement, textile, shoe, and nylon factories. Private-sector commercial buildings such as restaurants and hotels are common. Expanding factories to produce construction materials is a priority for Rojava, because reconstruction is absolutely necessary during and after the war. With the influx of refugees from the south there is an urban housing shortage, so the construction cooperatives are actively trying to build more residential space. Nonetheless, many refugees choose to continue onward to Europe, hoping for a better life. Since the region is so ravaged by war, it is hardly surprising that people want to flee abroad.

Despite the existence of a small private sector, not all typical capitalist industries are legal. Because of the history of underdevelopment and penury in Kurdistan, the people view loan sharks as unscrupulous parasites who cause more harm than good. Under the central government rule, banks did not bother to set up branches in the impoverished Kurdish periphery, so supplying credit to desperate people fell to very unpopular money lenders. Dr. Amaad Yousef explains how life was in the city he grew up in. "The one thing that developed was loansharking. In Efrin Reco district you would 
know which house belonged to whom. You could look at a house and say that's the house of a usurer". Since the people consider usury to be deeply immoral, the practice of charging interest is strictly forbidden. Those who do so are caught and tried by their neighbors. Under these unprofitable conditions the banking industry is nonexistent; Rojava has simply banned finance capital. ${ }^{49}$

Other telltale signs of a capitalist economy are absent in the cantons. In Rojava there are no malls, no skyscrapers, and no commercial billboards. All government employees, regardless of their post, receive the same low wage. Poverty is of course a problem in the underdeveloped northern borderlands of Syria, but Rojava's dedication to social equality is undeniable. Whether or not Rojava's economy will grow in times of peace is an open question, but at the very least the communal ties in West Kurdistan prevent starvation, common in times of war. ${ }^{50}$

A long history of poverty in Syria's northern hinterland and the ravages of war have created enormous problems for Rojava's economy. Trade is difficult with multiple closed borders and the necessity of funding military defense is an obvious burden of the economy. There is a persistent labor shortage, especially in agriculture, because so many people fled to the cities or abroad. Wartime casualties further aggravate the shortage of workers. Young people are particularly scarce in the labor force, because they are so urgently needed on the front lines. And since the cantons lack both centralized economic planning and private property relations, a sort of gift economy exists in Rojava today. People often gift non-commodified exchanges of supplies or labor, helping their community to get through hard times. When the war finally ends, it will be interesting to see what kind of economic policy Rojava will adopt. Will Rojava rely upon state planning to industrialize, or will the cantons revert to the more common market economics? Only time can tell. ${ }^{51}$

Rojava's communal economics is also unpopular with the merchant community that which struggles with inflation and has trouble importing goods. Business is difficult during the war when people are unlikely to spend money on anything beyond the absolute necessities. Diapers, electronics, and many medical supplies can only be bought across the border in Iraq, because the small cantons are unable to produce everything they need, despite how often they praise themselves as self-sufficient entities. Rojava grows plenty of food and extracts enough petrol from the ground to survive, but by international, including regional, standards its economy is tiny. ${ }^{52}$

Rojava hopes to develop industrially, but the cantons realize that their local cooperatives do not have the funds to bankroll heavy industry. In the future they will need at least a handful of major investors to expand the Rojavan economy. Obviously no business would invest millions of dollars in a warzone held by an internationally unrecognized entity, but after the war Rojava hopes to begin massive industrial projects. The estimated cost of rebuilding the petroleum refinery is USD 300 million. Constructing a large power plant costs USD 400 million, and even building a modest fertilizer or plastics factory requires USD 5 million of up-front capital. In the future Rojava will need greater clarity and legality of its status, in order to attract a few big investors. ${ }^{53}$ 
Nonetheless, the course of the civil war has (to the surprise of many Syrians) redefined the cantons as Syria's relative economic hub. Five years of grueling war have obliterated Syria's GDP, which has dropped by two-thirds since 2010. In 2016 Ahmed Yousef, chairman of Afrin University, estimated that the cantons may actually account for up to $55 \%$ of Syria's economic output, because Rojava has been the least war-torn region of Syria. Yousef may overestimate both Rojava's productivity and the level of destruction outside of the cantons, but his calculations suggest an intriguing reversal of fortunes, where Western Syria is no longer the most prosperous area. The cantons now have a modest civilian economy. Importing fertilizer, seeds, medicine, and machinery remains difficult for the cantons, and power outages are a persistent problem in times of war, but industries such as producing flour and blue jeans are growing at a steady rate. ${ }^{54}$

\section{Finding a solution to the Syrian civil war}

Although the cantons diverge from Damascus politically, they are nonetheless tied to the center economically. Rojava uses the Syrian pound as its currency, because the autonomous region does not have resources to direct monetary policy. The Assad government remains the biggest buyer of Rojavan petrol, because most of Syria has no oil resources. Despite the ongoing war, the cantons have improved their relations both with the Assad government and his ally Russia. Rojava officially seeks a UN-moderated resolution to the civil war and the cantons see Russia as an essential diplomatic actor in the cantons' favor. The Kurds absolutely do not trust proposals put forth by Turkey, Qatar, and Saudi Arabia, but they believe that the Russian diplomacy might benefit Rojava. It remains to be seen, however, whether and how much these expectations are justified.

On the one hand, Russia's bilateral military agreement with the Syrian government and direct military involvement have discouraged Turkey from full, large-scale military intervention in Syria. An evidence of improved relations between Rojava and Russia came on 10 February 2016, when the cantons opened a diplomatic office in Moscow, their first permanent diplomatic mission beyond Erbil in Iraqi Kurdistan. ${ }^{55}$ The cantons now have diplomatic offices in the Czech Republic, France, Germany, and Sweden ${ }^{56}$, and on 2 June 2016 the United Nations invited Rojava to the next round of Syrian peace talks. ${ }^{57}$ As relations between Turkey and Russia sharply deteriorated after the Turkish military shot down a Russian jet on 24 November 2015. Russia diplomatically supported the cantons for two reasons: partially in opposition to Turkey and in part to stabilize the region more generally.

On the other hand, with Moscow's new rapprochement with the Erdogan government since the summer of 2016, Russia has become quieter on Turkey's crossborder raids, including the more serious operation in northern Syria "Operation Euphrates Shield" ("Fırat Kalkanı" in Turkish) launched by the Turkish armed forces on 20 August 2016, with the official goal of fighting ISIS, but also attacking Kurdish targets. ${ }^{58}$ 
Despite the United States' open support for the Free Syrian Army, relations between the cantons and the United States also improved in 2015. Once the United States recognized ISIS as the gravest threat in the region in 2015, US airstrikes began supporting Rojava during its offensives against the "caliphate". The US and Russian planes do not bomb the Kurds, unlike Turkish artillery, which shelled Rojava 300 times between August and November 2015 alone. During the same period Turkey attacked ISIS on a mere three occasions. ${ }^{59}$

A possibility that both Rojava in Syria and the KRG in Iraq fear is that the world powers will use them as cannon fodder before abandoning Kurdistan diplomatically. The United States, Russia, and several European governments have praised the Kurds as skilled fighters, but they are far less enthusiastic about the regions' political programs, especially Rojava's philosophy of democratic confederalism. Both Rojava and the KRG agree that they do not want to be sacrificed by foreign powers, which care about the Kurds only because they are valuable as foot soldiers. However, Rojava and the KRG depend upon diplomatic allies who may not have their best interests at heart. ${ }^{60}$

Several rounds of international negotiations have been held to find a diplomatic solution to the Syrian catastrophe. Longstanding rivals sat down together to create a lasting solution to the war - including the United States and Russia, Iran and Saudi Arabia. Rojava must play an important role in these negotiations. Since the cantons are important actors in Syria, especially in the war against ISIS, they do expect to get a seat at the table. The cantons' political experiment has achieved a remarkable level of stability in the north of Syria, so a permanent solution to the armed conflicts in Syria and Iraq requires the full participation of Rojava. Even if Syria is going to be de facto divided into zones corresponding to areas controlled by the government, by self-governing cantons, and by Islamist rebels of varying degree of radicalism, then logically the global powers need to involve Rojava in the diplomatic process. ${ }^{61}$

On 17 March 2016 Rojava took the initiative to build a found the Federation of Northern Syria, a wide autonomy within whatever remains of the Syrian state. The cantons oppose the partition of Syria, realizing that there are macroeconomic and diplomatic advantages to being part of an internationally recognized sovereign state. At the same time, Rojava insists upon the maximum possible level of autonomy in a future Syria. Neither Damascus nor the world powers nor the quarreling rebel factions are in a position to dissolve the Federation of Northern Syria. The latter is also a model for decentralized government. After five years of bloody civil war, the decentralized political model championed by Rojava may be one way to achieve long-lasting peace in Syria. ${ }^{62}$

\section{Conclusion}

Even though the Rojavan cantons propagandize an inclusive revolutionary ideology, there is a certain irony regarding who receives their political message. Democratic confederalism is the mainstream and most popular model in Kurdishpopulated areas, the very neighborhoods that have been organizing for an ethnically 
united Kurdistan for several generations. So no matter how inclusive Rojava's ideology is on paper, in practice it is most readily embraced by people who speak Kurdish and want a Kurdish state. TEV-DEM members would deny the ethnic undertones to the cantons' borders, but they are themselves the products of 70 years of nationalistic mobilization. Rojava's socio-political ideology is civic and communal, but it is still a form of nationalism.

Nonetheless, Rojava has built a new form of egalitarian participatory democracy, which is especially impressive given that the heavily transnationalized and internationalized civil war in Syria is still raging on. The cantons technically (although not ideologically) resemble a Swiss-style political system that deemphasizes ethnic, religious, and linguistic differences, a federative model that rejects Baathism's chauvinistic history in Syria and Iraq. In March 2016 the cantons declared themselves to be the Federation of Northern Syria, a political arrangement that maximizes their autonomy within a future Syrian state. As an internationally supported, autonomous political entity, Rojava could help achieve a UN-negotiated resolution to the civil war.

Democratic confederalism is an ideology that combines civic nationalism and revolutionary socialism. It incorporates many telltale signs of nationalism - territorial claims, military service, flags, and martyr reverence - while at the same time organizing the entire community to remake society along egalitarian lines. Democratic confederalism uses participatory democracy and federalism to include the cantons' heterogeneous population in local politics. It is, however, highly questionable whether this unique solution could serve as a model for the cantons' neighbors.

\section{ENDNOTES}

1 Renan E. "What Is a Nation?". Lecture at the Sorbonne University, Paris, 11 March 1882. http://ucparis.fr/files/9313/6549/9943/What_is_a_Nation.pdf.

${ }^{2}$ Anderson B. Imagined Communities: Reflections on the Origin and Spread of Nationalism. Rev. ed. - L.: Verso, 2006.

${ }^{3}$ Gellner E. Nations and Nationalism. - Ithaca: Cornell University Press, 1983.

${ }^{4}$ Guibernau M. Nations Without States: Political Communities in a Global Age. - Malden, MA: Blackwell Publishers, 1999.

${ }^{5}$ Hechter M. Containing Nationalism. - Oxford: Oxford University Press, 2000.

${ }^{6}$ For more detail, see McDowall D. A Modern History of the Kurds. 3d rev. ed. - L.: I.B.Tauris, 2004.

${ }^{7}$ Ibid.

${ }^{8}$ Madra Y.M. Democratic Economy Conference: an introductory note // South Atlantic Quarterly. V. 115. № 1. January 2016. P. 211-222. 
${ }^{9}$ Krajeski J. What the Kurds want // Virginia Quarterly Review. V. 91. № 4. Fall 2015. P. 86-105.

${ }^{10}$ McDowall D. Op. cit.

${ }^{11}$ Paasche T.F. Syrian and Iraqi Kurds: conflict and cooperation // Middle East Policy. V. 22. № 1. Spring 2015. P. 77-88.

12 Leverink J. The revolution behind the headlines: autonomy in Northern Syria // Telesur. 22 February 2015. http://www.telesurtv.net/english/opinion/The-Revolution-Behind-the-HeadlinesAutonomy-in-Northern-Syria-20150222-0011.html.

${ }^{13}$ Markey P. After quiet revolt, power struggle looms for Syria's Kurds // Reuters. 7 November 2012.

14 Küçük B., Özselçuk C. The Rojava experience: possibilities and challenges of building a democratic life // South Atlantic Quarterly. V. 115. № 1. January 2016. P. 184-196.

${ }^{15}$ Callimachi R. ISIS enshrines a theology of rape // The New York Times. 13 August 2015.

${ }^{16}$ Inside Kobane // BBC. 4 January 2015 (accessed through Youtube. 18 May 2016).

${ }^{17}$ Cockburn P. End times for the Caliphate? // London Review of Books. V. 38. № 5. 3 March 2016.

P. 29-30.

${ }^{18}$ Ibid.

${ }^{19}$ Reuters. PKK, ISIL are the same, says Erdoğan // Today's Zaman. 4 October 2014.

${ }^{20}$ Kurds take control in Syria's Northeast // Al Jazeera. 12 August 2012.

${ }^{21}$ Leverink J. Op. cit..

22 Ibid.

${ }^{23}$ Enzinna W. A dream of secular utopia in ISIS' backyard // The New York Times. 24 Nov. 2015.

${ }^{24}$ Ross C. Power to the people: a Syrian experiment in democracy // Financial Times. 23 October 2015.

${ }^{25}$ Krajeski J. Op. cit.

${ }^{26}$ Miley J., Riha J. Can the revolution in Kurdish Syria succeed? // University of Cambridge Research: Discussion. 2 February 2015. http://www.cam.ac.uk/research/discussion/can-therevolution-in-kurdish-syria-succeed.

${ }^{27}$ Leverink J. Op. cit.

${ }^{28}$ Ross C. Op. cit.

29 Rojava: Syria's secret revolution // BBC Our World. 14 November 2014. (accessed through Youtube. 12 Dec. 2015).

${ }^{30}$ Miley J. et al. Op. cit. 
${ }^{31}$ Rojava: Syria's secret revolution. Op. cit.

32 Enzinna W. Op cit.

${ }^{33}$ Owen M. Gender and justice in an emerging nation: my impressions of Rojava, Syrian Kurdistan // Ceasefire. 11 February 2014.

${ }^{34}$ Krajeski J. Op. cit.

35 Üstündağ N. Self-defense as a revolutionary practice in Rojava, or how to unmake the state // South Atlantic Quarterly. V. 115. № 1. January 2016. P. 197-210.

${ }^{36}$ Ross C. Op. cit.

${ }^{37}$ Küçük B., Özselçuk C. Op. cit.

38 Üstündağ N. Op. cit.

${ }^{39}$ Enzinna W. Op. cit.

${ }^{40}$ Krajeski J. Op. cit.

${ }^{41}$ Paasche T.F. Op. cit.

42 Hemo A. Rojava's threefold economy / Transl by J.Biehl // Ecology or Catastrophe. Web-blog. 25 February 2015. http://www.biehlonbookchin.com/rojavas-threefold-economy/.

${ }^{43}$ Ibid.

${ }^{44}$ Yilmaz S. Efrin Economy Minister Yousef: Rojava challenging norms of class, gender and power // Diha. 22 December 2014.

${ }^{45}$ Miley, J. et al. Op. cit.

${ }^{46}$ Yilmaz S. Op. cit.

47 A Small Key Can Open a Large Door: The Rojava Revolution. - Strangers in a Tangled Wilderness, 2015. http://www.tangledwilderness.org/about; http://www.combustionbooks.org/products-page/non-fiction/a-small-key-can-open-a-large-door-therojava-revolution/.

${ }^{48}$ Yilmaz S. Op. cit.

49 Ibid.

50 Gupta R. Rojava: a safe haven in the middle of Syria's brutal war // CNN. 30 March 2016. http://edition.cnn.com/2016/03/30/opinions/rojava-kurds-syria-democracy (accessed 18 May 2016).

${ }^{51}$ Küçük B., Özselçuk C. Op. cit.

${ }^{52}$ Krajeski J. Op. cit. 
${ }^{53}$ Hemo A. Op. cit.

54 Drwish S.M. Will Syria's Kurds succeed at self-sufficiency? // Al-Monitor. 3 May 2016. http://www.al-monitor.com/pulse/originals/2016/04/kurdish-areas-norther-syria-economy-self-

sufficiency.html (accessed 4 July 2016).

55 Van Wilgenburg W. Syrian Kurdish forces to inaugurate first representation office in Czech Republic // ARA News. 31 March 2016. http://aranews.net/2016/03/syrian-kurdish-forces-inauguratefirst-representation-office-czech-republic/ (accessed 18 May 2016).

${ }^{56}$ Agence France-Presse, Syrian Kurds open unofficial representative mission in Paris // Al Arabiya English. 24 May 2016. https://english.alarabiya.net/en/News/middle-east/2016/05/24/Syrian-Kurdsopen-unofficial-representative-mission-in-Paris-.html (accessed 18 July 2016).

57 Arafat H. Syrian Kurdish PYD to participate in Geneva Talks // Kurdistan 24. 6 June 2016. http://www.kurdistan24.net/en/news/6870f52d-5bad-4248-a34f-c7c4a75902bb/Syrian-Kurdish-PYDinvolvement-confirmed-in-Geneva-talks (accessed 18 July 2016).

58 Zaman A. PYD leader: Russia will stop Turkey from intervening in Syria // Al Monitor. 1 October 2015.

${ }^{59}$ Enzinna W. Op. cit.

${ }^{60}$ Cockburn P. Op. cit.

${ }^{61}$ The Kurds' push for self-rule in Syria // The New York Times. 21 March 2016.

${ }^{62}$ Containing multitudes // The Economist. 26 March 2016. 